RADOVI

Zavoda za znanstveni rad

HAZU Varaždin
UDK 681.817.1-051Klima, J. Izvorni znanstveni članak Original Scientific Paper

Primljeno: 03. 07. 2017.

Prihvaćeno: 11. 10. 2017.

JANKO RANOGAJEC

Glazbena škola Zlatka Balokovića, Zagreb

DOI: https://dx.doi.org/10.21857/y54jofpgkm

\title{
JOSIP KLIMA - JEDNA SVESTRANA UMJETNIČKA I PEDAGOŠKA OSOBNOST
}

\begin{abstract}
U radu se obrađuje i kronološki prikazuje pedagoško djelovanje i umjetnička karijera violinista Josipa Klime. Pored toga kratko je prezentirana njegova angažiranost u sferi glazbenog amaterizma, te sklonost oživljavanju salonske glazbe.
\end{abstract}

Izbjegavao je vožnju kružnim tokom. Vožnju unazad („u rikverc“ - kako je sâm govorio) nije nikada prakticirao, a dokazao je i omiljenu izreku „Znam voziti samo naprijed“: tijekom čitave iznimno uspješne umjetničke karijere kretao se uvijek naprijed. ${ }^{1}$

U mnogim neposrednim radnim kontaktima imao sam priliku kao student violine na Muzičkoj akademiji u Zagrebu, a kasnije i kao profesionalni glazbenik u ansamblima Opere HNK u Zagrebu i Simfonijskog orkestra HRT-a, upoznati Josipa Klimu kao osobu i glazbenika. Prilikom suradnje iskazivao je taktičnost u komunikaciji, ali i suverenost glazbeničkog autoriteta. Prema mojim iskustvima bio je uvijek srdačan u ophođenju, a istovremeno zahtjevan u pogledu preciznosti i sugestivnosti izvedbe djela s repertoara.

\section{NEKE BIOGRAFSKE ODREDNICE}

Josip Klima, rođeni Varaždinac (3. ožujka 1927.), od svojih je prvih koraka bio tijesno povezan s glazbom. Njegov otac, Karlo Klima, podrijetlom Čeh, bio je vojni muzičar, a kao vrsni glazbenik u Varaždinu je obnašao dužnost dirigenta vojne

Prema obavijesti Vedrana Mikića nekadašnjeg studenta prof. J. Klime, dobivenoj dana 25. 4. 2017. godine. 
glazbe. Prvu poduku iz violine dobio je upravo od svog oca. Prema navodima Krešimira Filića, osnovnu i građansku školu Josip Klima je završio u Varaždinu. ${ }^{2}$ Drugi izvori upućuju na zaključak da je 1945. godine u Zagrebu završio gimnaziju, a od 1940. do 1946. usporedo u Zagrebu pohađao srednju glazbenu školu u violinskoj klasi prof. Ladislava Miranova. ${ }^{3}$ Potom, od 1947. do 1950. upisuje, studira i apsolvira violinu na Muzičkoj akademiji u Zagrebu u klasi prof. Vaclava Humla. Već 1950. godine postaje koncertnim majstorom orkestra HNK u Zagrebu. Studij violine nastavlja 1951. u Parizu na École normale de musique u razredu profesorice Yvonne Astruc, gdje je 1953. diplomirao dobivši „Licence de Concert violon". Čini se da je bio najbolji apsolvent ${ }^{4} \mathrm{i}$ diplomant ${ }^{5}$ te godine. Po povratku u Zagreb, 1953. godine preuzima poziciju koncertnog majstora Zagrebačke filharmonije. Istovremeno s tom dužnošću, od 1954. do 1957. član je prvog sastava ansambla Zagrebačkih solista u vrijeme umjetničkog vodstva proslavljenog čelista i pedagoga Antonia Janigra. Treba napomenuti da Ivona Ajanović-Malinar navodi da je u ansamblu Zagrebačkih solista djelovao od 1955. do $1956 .{ }^{6} \mathrm{U}$ isto vrijeme, 1954., inicira obnovu Zagrebačkog kvarteta po uzoru na istoimeni ansambl osnovan 1919. godine, koji je početkom Drugoga svjetskog rata prestao djelovati. Osnovu za njegovu obnovu nalazi u radu Akademskog gudačkog kvarteta formiranog tijekom njegovih zagrebačkih studentskih dana u sastavu: Josip Klima, Tomislav Šestak, Dušan Stranić i Zvonko Pomykalo. Prema nekim izvorima J. Klima ostaje na čelu tog kvarteta do $1975 .{ }^{7}$ dok drugi izvori navode 1977 . godinu. ${ }^{8}$ Godine 1980. utemeljuje Gudački kvartet „Stratik“, ${ }^{9}$ koji je godinu dana kasnije preimenovan u Kvartet „Klima“"10 s kojim je nastupao do 1997. godine.

2 Krešimir FILIĆ, Glazbeni život Varaždina, Varaždin, Muzička škola Varaždin, 1972., str. 514.

3 Ivona AJANOVIĆ-MALINAR, Klima, Josip, Hrvatski biografski leksikon, http://hbl.lzmk.hr/clanak. aspx?id=10527 (pristup 5. 5. 2017.).

4 Lovro ŽUPANOVIĆ, Violinista Josip Klima u svjetlu francuske kritike, Vjesnik, 15(1954) 2846, str. 6.

5 I. AJANOVIĆ-MALINAR, Klima, Josip, Hrvatski biografski leksikon, http://hbl.lzmk.hr/clanak. aspx?id=10527 (pristup 5. 5. 2017.).

6 I. AJANOVIĆ-MALINAR, Klima, Josip, Hrvatski biografski leksikon, http://hbl.lzmk.hr/clanak. aspx?id=10527 (pristup 5. 5. 2017.).

7 Dossier Josipa Klime, Muzička akademija Sveučilišta u Zagrebu.

8 I. AJANOVIĆ-MALINAR, Klima, Josip, Hrvatski biografski leksikon, http://hbl.lzmk.hr/clanak. aspx?id=10527 (pristup 5. 5. 2017.).

9 Gudački kvartet „Stratik“ djelovao je u sastavu: Josip Klima, Mladen Sedak, Daniel Thune, Bojan Lhotka.

10 Gudački kvartet „Klima“ djelovao je u sastavu: Josip Klima, Mladen Sedak, Dragan Rucner, Snježana Rucner. 


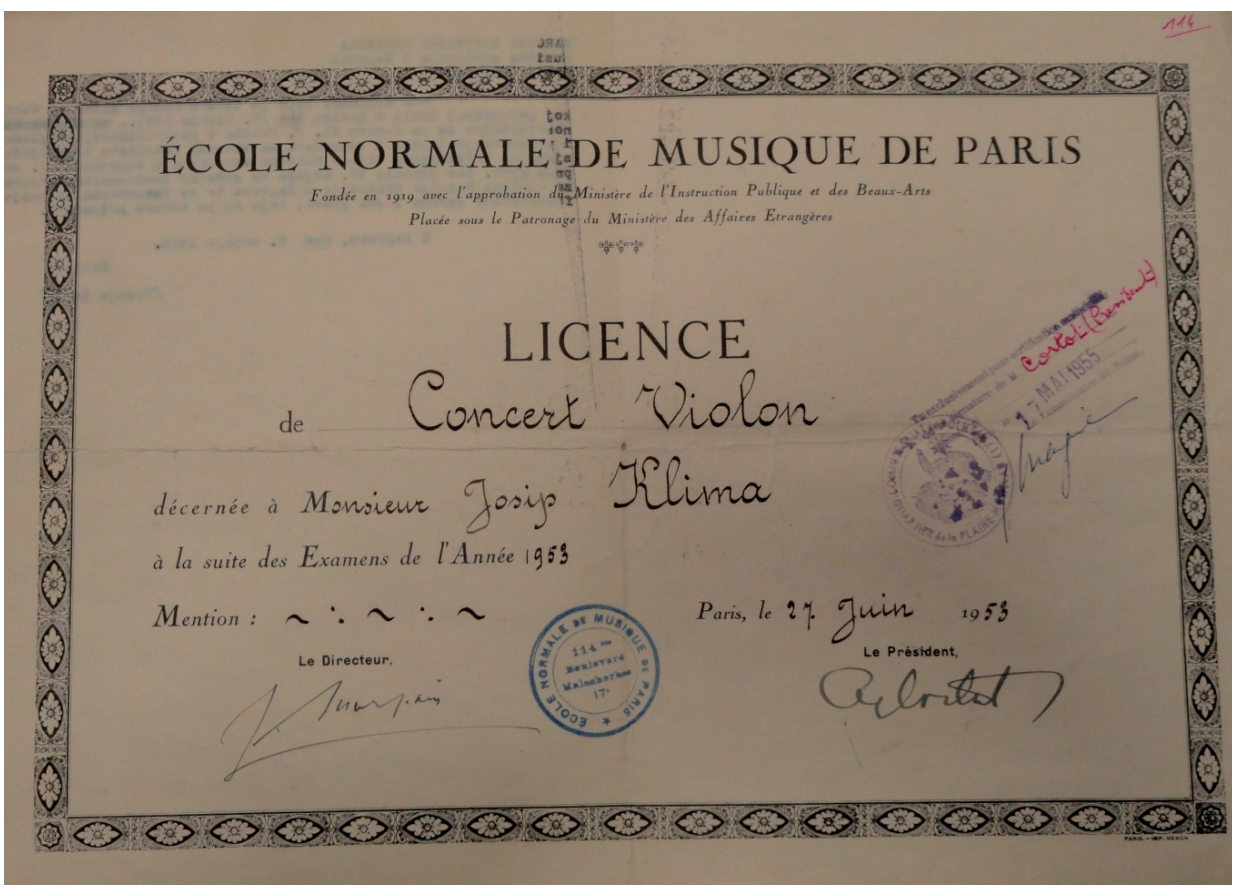

Slika 1. Original diplome Josipa Klime s École normale de musique de Paris, 27. 6. 1953. godine.

Prva pedagoška iskustva stječe na Muzičkoj akademiji u Zagrebu 1957. gdje u svojstvu honorarnog nastavnika za kolegij Violina djeluje do travnja 1958. godine. Daljnja pedagoška aktivnost vodi ga u Egipat kao profesora violine na Nacionalnom konzervatoriju u Kairu u razdoblju od 1959. do 1961. godine. Povratkom u Zagreb sljedeće takvo iskustvo nastavlja u ulozi nastavnika violine na Muzičkoj školi „Vatroslava Lisinskog“ u periodu od 1961. do 1962. godine. Usporedo je od 1961. do 1965. ponovno koncertni majstor Opernog orkestra u Zagrebu, a od 1965. do 1967. i Zagrebačke filharmonije. Od 1965. prelazi u status slobodnog umjetnika kojeg kao solist i prvi violinist Zagrebačkog kvarteta zadržava do 1975. godine.

Godine 1973. javlja se na natječaj Muzičke akademije u Zagrebu za radno mjesto nastavnika za kolegije Violina i Komorna muzika u Gudačkom odjelu, u zvanju honorarnog docenta. Kao honorarni nastavnik na Muzičkoj akademiji djeluje do 1975., potom se zapošljava na mjestu producenta programa u Koncertnoj dvorani Vatroslava Lisinskog, a napušta ga 1978. u statusu šefa propagande. Od toga trenutka pa sve do umirovljenja 1994. neprekidno je zaposlen kao pedagog na Muzičkoj akademiji, isprva u svojstvu nastavnika za kolegije Violina i Komor- 
na glazba u zvanju docenta, a potom od 11. 1. 1984. stječe naslov redovitog profesora. ${ }^{11}$ Uz navedene predmete povremeno predaje Metodiku nastave violine te Studij orkestralnih dionica. "Znanstveno-nastavno zvanje redovitog profesora" (kako stoji u dossieru Muzičke akademije) potvrđuje se 1989., a Odlukom Senata Sveučilišta u Zagrebu od 27. travnja 1995. izabran je u trajno zvanje. Nakon umirovljenja, pa sve do 2002. predaje Komornu glazbu kao vanjski suradnik. Već tijekom studija započinje koncertnu karijeru najčešće u suradnji s pijanistom Juricom Murajem, te solističkim nastupima uz pratnju orkestara. Daljnja koncertna djelatnost vezana je uz nastupe u sastavu Zagrebačkih solista, a svjetsku umjetničku karijeru postigao je s proslavljenim Zagrebačkim kvartetom s kojim je gostovao na svim kontinentima, te na brojnim festivalima od kojih valja istaknuti Salzburške ljetne igre i Varšavsku jesen. Uvijek se vraćao domaćoj publici sudjelujući na Dubrovačkim ljetnim igrama, Varaždinskim baroknim večerima i zagrebačkom Muzičkom biennalu. U svom opsežnom repertoaru od barokne, klasičke, romantičke do suvremene glazbe, nije zaboravljao promicati domaće hrvatske autore poput Ivana Zajca, Božidara Kunca, Franje Krežme, Borisa Papandopula, Natka Devčića, Stanka Horvata, Rubena Radice i drugih, a isto tako je imao čast mnoge od njih praizvesti primjerice Brunu Bjelinskog, Željka Brkanovića, Milu Cipru, Emila Cossetta i već spomenute N. Devčića i B. Papandopula.

“Kvartet, gudački kvartet je moja stalna i vječita ljubav (...) rodila mi se ideja da kvartet ne radimo usput nego da to bude primarno naše zvanje, dakle iz kvartetskog rada napravimo svoju profesiju (...) Mislim da je to urodilo plodom, ne samo u kvaliteti sviranja, jednom profesionalnom angažmanu u tome, nego smo potaknuli niz značajnih domaćih kompozitora da napišu upravo baš za Zagrebački kvartet svoja djela. Sa zadovoljstvom moram konstatirati da je na desetke i desetke djela tako nastalo, da su mnogi od tih kvarteta kao djela dobili niz priznanja i nagrada i mislim da, u svakom slučaju danas najjednostavnije mogu reći da se to isplatilo svima nama, cijeloj muzičkoj našoj sredini". ${ }^{12}$

\section{O UMJETNIČKOM DJELOVANJU I RECEPCIJI}

Klima je bio svestrana osoba i glazbenik širokog spektra, a ta svestranost ogledala se $u$ angažmanu na različitim poljima kulturne djelatnosti. U glazbe-

11 Dossier Josipa Klime, Odluka Savjeta Akademije, Muzička akademija Sveučilišta u Zagrebu, Zagreb, 11. 1. 1984.

12 Judita KORBLER, Josip Klima, emisija „Vrijeme je za muziku“, Hrvatski radio, Treći program, emitirano 17. 10. 1978. godine. Pod tim je datumom emisija evidentirana u arhivi HRT-a, iako Gordana Krpan navodi da je emitirana u veljači 1979., http://www.ihg.hr/novosti/josip-klima-1927-2012-71 (pristup 5. 5. 2017.). 
ničkom smislu okušao se u svim vidovima aktivnosti od orkestralnog glazbenika na istaknutim solističkim pozicijama u različitim orkestrima u Hrvatskoj, komornog glazbenika svjetskog ugleda, do soliste kako u domeni ozbiljne tako i zabavne glazbe. Njegove interpretacije odlikovale su se tehničkom sigurnošću, ali i svojim osobitim izražajnim osobnim i umjetničkim šarmom. U svoje izvedbe mnogobrojnih autora različitih stilskih epoha, uz obvezno poštivanje stilskih obilježja, unosio je svoju osobnost. Isticao se punoćom i toplinom tona, profinjenošću izražaja, temperamentom i sugestivnošću svirke. O kvaliteti njegovih izvedbi govore pohvalne kritike u brojnim tiskanim medijima, poput Vjesnika, Borbe, Oka, Slobodne Dalmacije i drugih. Već i sami naslovi pojedinih članaka govore tome $\mathrm{u}$ prilog: „Nezaboravni užitak“, „Impresivni susret s Borisom Papandopulom“ i „Profinjeno".

Tako Vjesnik u srijedu u svom članku „Profinjeno“ autora Nikše Gliga objavljuje: „Klima je bio toliko suveren u svojim zadacima da smo se morali još jednom posvetiti njegovu solističkom come-backu. Daleko od rutinskog isviravanja svoje i tehnički i te kako komplicirane dionice, on se u Brahmsovu glazbu bacio svom energijom svoje profinjene muzikalnosti i upriličio nam tako gotovo nezaboravan doživljaj". ${ }^{13}$

Njegov istraživački poriv dovest će do neprestanog traganja za novim, ali i otkrivanja zaboravljenih i neopravdano zapostavljenih djela domaćih autora. Sjetimo se samo praizvedbe Papandopulova koncerta za violinu i orkestar.

Glazbena kritičarka Jagoda Martinčević, u glasilu Hrvatskog glazbenog zavoda u članku „In memoriam - J. Klima“ ističe: „Kao solist i komorni glazbenik brinuo se za hrvatsku glazbu kao malo tko...., sjajne su interpretacije violinskih koncerata Ivana pl. Zajca, Borisa Papandopula, Božidara Kunca, Željka Brkanovića, a treba samo poslušati njegove snimke Dvořaka i Bruchova violinskog koncerta, kako bi se podsjetilo kakvog smo guslačkog mahera imali“ ${ }^{14}$

Brojne su njegove radijske i televizijske snimke izvedbi, a pored toga je snimio LP ploče, kazete i CD-e od kojih treba izdvojiti LP „Suvremeni hrvatski glazbenici za violinu i glasovir"s Vladimirom Krpanom (Jugoton, 1976.) i sve Beethovenove sonate za violinu i klavir s Juricom Murajem (Jugoton, 1979.). U okviru žanra popularne glazbe ne treba zaboraviti suradnju Josipa Klime sa skladateljem, pijanistom i aranžerom Stjepanom Mihaljincem iz koje su proizašla dva LP albuma „Ko lijepi san“ 1987. i „Ne zaboravi me“ 1989. u izdanju Jugotona.

13 Nikša GLIGO: „Profinjeno“, Vjesnik u srijedu, 26(1977),1289, str. 31.

14 Jagoda MARTINČEVIĆ: In memoriam Josip Klima, Ha-Ge-Ze glasilo Hrvatskog glazbenog zavoda, XVI (2012), 1, str. 3. 
Preminuo je 6. lipnja 2012. u Zagrebu u 86. godini života. Kao član Zagrebačkog kvarteta dobitnik je brojnih domaćih i inozemnih prestižnih nagrada, a kao svestrani umjetnik za osobni doprinos i zasluge u kulturi dodijeljene su mu sljedeće nagrade:

1. Godišnja nagrada Vladimir Nazor Ministarstva kulture, 1981.

2. Nagrada Milka Trnina HDGU, 1986.

3. Plaketa HDGU povodom 40. obljetnice umjetničkoga rada, 1994.

4. Nagrada Vladimir Nazor za životno djelo, 2000.

5. Nagrada Porin za životno djelo, 2011. ${ }^{15}$

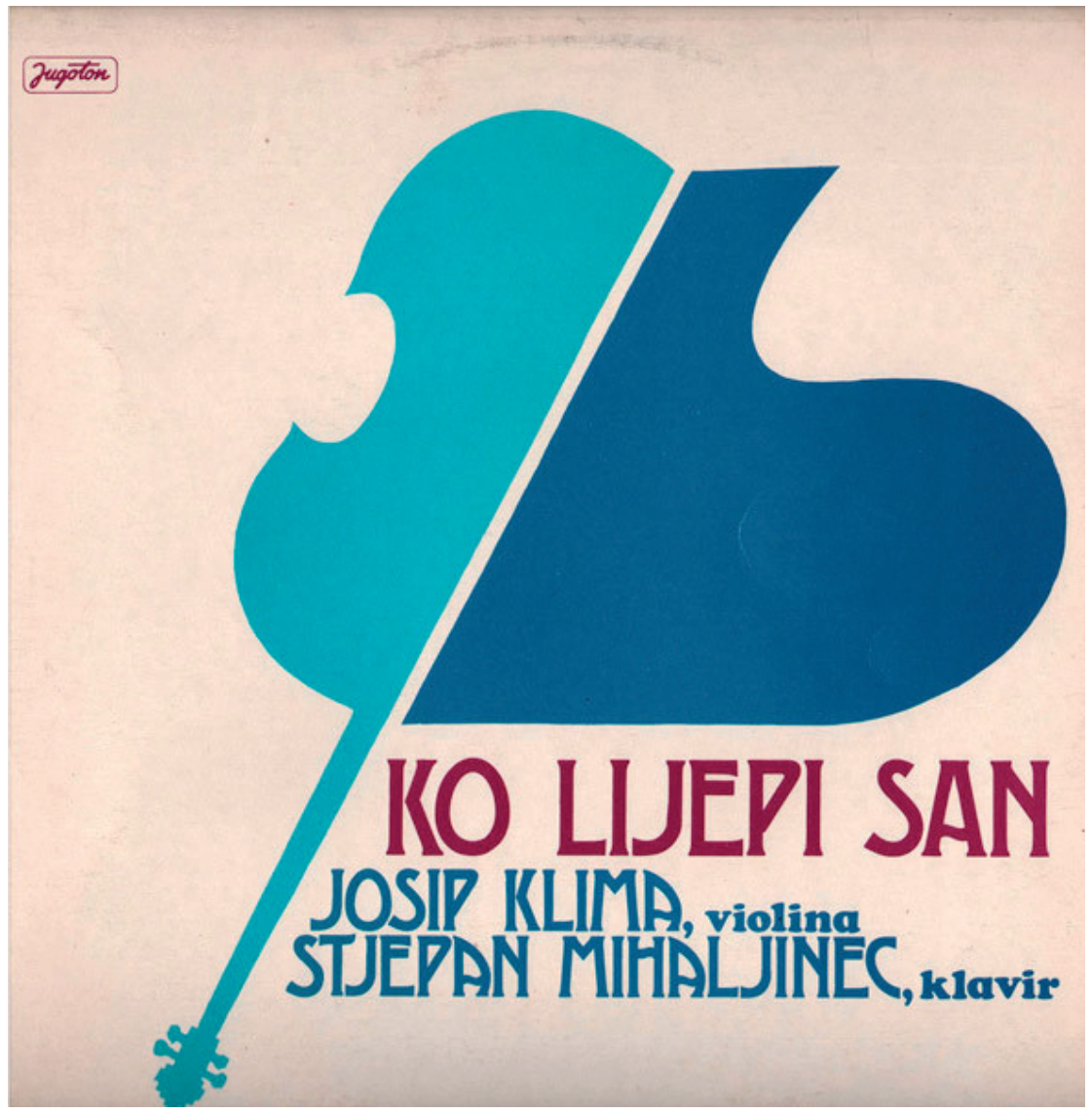

Slika 2. Omotnica LP ploče „Ko lijepi san“

15 Wikipedia: Josip Klima, Nagrade i priznanja, https://hr.wikipedia.org/wiki/Josip_Klima (pristup 15. 5. 2017.). 
Janko Ranogajec: Josip Klima - jedna svestrana umjetnička i pedagoška osobnost

Radovi Zavoda za znanstveni rad HAZU Varaždin; br. 29, 2018., str. 309-321

\section{PEDAGOŠKO DJELOVANJE}

Prilikom izbora na radno mjesto docenta za violinu i komornu glazbu u obrazloženju „Zaključka komisije za izbor kandidata“ Muzičke akademije u Zagrebu sa sjednice održane 20. rujna 1978. stoji da je bio vrhunski umjetnik, violinist koncertant, koncert majstor naših renomiranih orkestara, ambasador naše kulture u svijetu, a ističe se: „Klima je umjetnik koji se odlikuje briljatnom tehnikom i temperametnim izvođenjem djela za violinu“ ${ }^{16}$

U Izvještaju stručne komisije u postupku izbora nastavnika Muzičke akademije u Zagrebu sačinjenom 18. travnja 1989. prilikom njegova reizbora za redovitog profesora navodi se: „Josip Klima je instrumentalist iskonskog temperamenta i ogromna iskustva". ${ }^{17}$

"Za mene to jako puno znači. Dugo se bavim mišlju da sva moja iskustva koja sam stekao tokom godina imam mogućnosti prenositi na mlađe generacije i evo sad mi se pružila prilika (...) To me neobično raduje. U prvom redu je to priznanje mom dosadašnjem radu, a drugo što ću biti u mogućnosti da sa svog radnog mjesta prenašam sve ono što sam tokom tih 20-25 godina naučio i do kojih saznanja sam došao i koja sam saznanja stekao. I sad predstoji predamnom jedino da povjerenje koje mi je tako Muzička akademija iskazala, da opravdam sa svojim rezultatima". ${ }^{18}$

Tako je u eter govorio prof. Klima netom nakon nastupa na mjesto docenta violine na Muzičkoj akademiji. Tendenciju da svoja sviračka i umjetnička znanja i iskustva prenese na mlade, ostvarivao je u više navrata, a od 1978. započinje njegovo kontinuirano bavljenje pedagoškim radom. Kao učenik iz klase renomiranog violinističkog pedagoga i utemeljitelja Zagrebačke violinističke škole prof. Vaclava Humla zasigurno je posjedovao kvantum znanja obogaćen saznanjima stečenim za vrijeme studija u Parizu, te iskustvima iz koncertantne prakse kojima je imao čemu podučiti studente, polaznike njegove klase Akademije u Zagrebu. Premda se intonativna i tehnička preciznost izvedbe, po uzoru na svog učitelja Humla, nametala kao imperativ, nije na tome previše inzistirao, te je i u svom pedagoškom radu iskazivao osobit pristup. Iz navoda njegovog posljednjeg studenta i diplomanta Vedrana Mikića, imao je razumijevanja i za pokoju izvođačku pogrešku svojih studenata u korist muzikalnosti, napominjući pri tome da smo svi mi ljudska bića sklona greškama. Duljina trajanja njegovih predavanja, uz

16 Dossier Josipa Klime, Zaključak komisije za izbor kandidata, Muzička akademija Sveučilišta u Zagrebu, Zagreb, 20. 9. 1978. godine.

17 Dossier Josipa Klime, Izvještaj stručne komisije u postupku izbora nastavnika, Muzička akademija Sveučilišta u Zagrebu, Zagreb, 18. 4. 1989. godine.

18 Judita KORBLER urednica i autorica emisije „Vrijeme je za muziku-Josip Klima“ Arhiv Hrvatskog radija, Treći program, 17. 10. 1978. godine. 
neizostavnu cigaretu, nije ga nikada zanimala. Ako bi student došao na nastavu priređen, mogao je taj sat violine potrajati i dulje od uobičajenog. Satovi nisu bili jednolični, katkad je radio na tehnici, a ponekad izričito na zadanom programu. No ono što je uvijek zahtijevao, bio je lijep ton i osobnost izražaja. Često je naglašavao "Gudač se od gudača razlikuje samo po desnoj ruci“. ${ }^{19}$ Volio je i poticao temperametno i strastveno sviranje kakvo je i sam prakticirao. U komunikaciji je bio srdačan i topao, ali je znao iskazati i oštro negodovanje ako se netko od studenata nije dobro priredio. Autoritet je postizao posežući za svojom violinom, osobnim izvođenjem pojedinih dijelova neke skladbe ili dionice. Prema nekim navodima njegovih studenata, iznimno kvalitetno i nadahnuto je predavao djela za violinu francuskih skladatelja, osobito Césara Francka i Claudea Debussyja. ${ }^{20}$ Sve ove odlike mogle su se uočiti ne samo na individualnim nego i na satovima kolegija Studija orkestralnih dionica i Komorne glazbe, koju je izrazito preferirao. Osim studentima Akademije, svoje ogromno znanje i umijeće prenosio je i na raznim domaćim i međunarodnim seminarima, primjerice u okviru Muzičke omladine u Grožnjanu i u Belgiji. ${ }^{21}$ Također je bio članom ocjenjivačkih sudova brojnih učeničkih i studentskih natjecanja, međunarodnih žirija primjerice u Italiji ${ }^{22}$, kao i žirija uglednog Međunarodnog violinističkog natjecanja „Vaclav Huml“ (1989). Kao pedagog postizao je zapažene uspjehe $u$ radu, a posebno treba izdvojiti prvu nagradu njegovih studenata osvojenu na Jugoslavenskom natjecanju muzičkih umjetnika u disciplini gudački kvartet, održanom 1988. u Zagrebu. ${ }^{23}$ Laureat tog natjecanja bio je Gudački kvartet Baloković u sastavu Nenad Nežmah, Josip Novosel ml., Aleksandar Milošev i Augustin Mršić, čiji je mentor i umjetnički voditelj bio profesor Klima. Naime, spomenuti kvartet formiran je na Kliminu inicijativu 1985. pod imenom Gudački kvartet Muzičke akademije, kasnije preimenovan u „Baloković“ od vrsnih studenata Muzičke akademije. ${ }^{24}$ Nažalost vrlo perspektivna umjetnička karijera mladog ansambla prekinuta je odlaskom dvaju članova (A. Milošev i N. Nežmah) izvan granica Hrvatske.

19 Prema obavijesti V. Mikića nekadašnjeg studenta prof. J. Klime, dobivenoj dana 25. 4. 2017. godine.

20 Prema obavijesti Vande Novoselec nekadašnje studentice prof. J. Klime, dobivenoj dana 11. 5. 2017. godine.

21 Dossier Josipa Klime, u priloženom životopisu, Muzička akademija Sveučilišta u Zagrebu, Zagreb.

22 Dossier Josipa Klime, u obrazloženju Izvještaja stručne komisije u postupku izbora nastavnika, Muzička akademija Sveučilišta u Zagrebu, Zagreb, 18. 4. 1989. godine.

23 Prema obavijesti Augustina Mršića člana Gudačkog kvarteta Muzičke akademije, dobivenoj dana 26. 4. 2017.

24 Prema obavijesti Augustina Mršića, Josipa Novosela ml. i Aleksandra Miloševa tadašnjih članova Gudačkog kvarteta Muzičke akademije, dobivenoj dana 26. 4. 2017. godine. 
Janko Ranogajec: Josip Klima - jedna svestrana umjetnička i pedagoška osobnost

Radovi Zavoda za znanstveni rad HAZU Varaždin; br. 29, 2018., str. 309-321

Njegova je klasa okupljala talentirane i uspješne violinistice i violiniste. $\mathrm{Ne}$ treba zaboraviti da je njegov učenik Željko Haliti još za vrijeme studija izveo virtuozni Koncert za violinu i orkestar u fis-molu Henryka Wieniawskog nakon dugog perioda njegovog neizvođenja u Zagrebu. Potrebno je istaknuti njegove postdiplomante Gorana Končara, danas uglednog solista i profesora violine na Muzičkoj akademiji i Volodju Balžalorskog, profesora violine na Akademiji za glasbo Univerze v Ljubljani. Od ostalih studenata treba spomenuti Nenada Nežmaha danas vođu drugih violina opernog orkestra Stadttheatera u Klagenfurtu, Mojcu Ramuščak koncertnu majstoricu orkestra HNK u Zagrebu, Eleonoru Ernoić zamjenicu koncertnog majstora istog orkestra, Vesnu Kolacio vođu drugih violina Opernog orkestra u Rijeci, uz brojne druge njegove studente članove različitih orkestara, komornih ansambala ili nastavnike u glazbenim školama. Unutar pedagoške aktivnosti Klima je obradio za edukativne i izvodilačke potrebe skladbe L. Županovića Balkanski ples broj 1 i Dore Pejačević Pet minijatura za violinu i klavir. ${ }^{25}$

\section{BRIGA ZA AMATERIZAM I SKLONOST PREMA SALONSKOJ GLAZBI}

Njegova zaokupljenost glazbom očitovala se i u radu s amaterima, pa je na njegov poticaj osnovan Komorni ansambl „Novi Zagreb“ čijim je umjetničkim voditeljem bio u razdoblju od 1978. do 1997. godine. Brigu i pažnju o amaterskom glazbenom izražaju posvetio je preuzevši i umjetničko vođenje Ansambla Pučkog otvorenog učilišta utemeljenog u travnju 1999. godine. Ansambl je osnovan radi okupljanja ljubitelja glazbe koji su se radovali zajedničkom muziciranju. U početku je bio sastavljen od glazbenih amatera i umirovljenih glazbenika, a potom su mu se pridružili zainteresirani učenici glazbenih škola kao i pokoji profesionalni glazbenik. Rad ansambla se odvijao u obliku glazbene radionice s više manjih komornih sastava pod stručnim nadzorom prof. Klime. Nakon kontinuiranih tjednih proba, jednom mjesečno je bio organiziran javni nastup pod nazivom „Glazbeni petak u knjižnici“. Repertoar ovog ansambla se većinom sastojao od izvedbi djela baroknih, klasičkih i romantičkih skladatelja, ali i ponekog domaćeg autora i drugih. Pored nastupa prilikom različitih kulturnih događanja u Pučkom otvorenom učilištu Zagreb svoje koncerte ansambli su priređivali i u domovima umirovljenika, Češkoj besedi, Maloj dvorani Lisinski i Hrvatskom glazbenom zavodu. Prema dostupnim podacima, 2007. godine iz ovog su ansambla proistekla dva nova: Društveni komorni ansambl Hrvatskog glazbenog

25 Pet minijatura za violinu i klavir / Dora Pejačević ; urednik Koraljka Kos ; priredio i uvodnu studiju napisao Ladislav Šaban; obrada violinske dionice Josip Klima 1985.[Notna građa] (usp. http://www.mic.hr/products/miniatures-for-violin-and-piano). 
zavoda i Ansambl salonske glazbe „Animato”. ${ }^{26}$ Znatan je dio svojeg vremena Pepi, kako su ga mnogi od milja zvali, posvećivao mladima, posebice studentima Muzičke akademije, budućim glazbenim profesionalcima. Glazbeno puritanstvo mu je bilo strano, te nije zazirao od popularnijih vidova glazbe. Širokogrudnost je pokazivao nesklonošću zanemarivanja popularnih skladbi ležernijeg karaktera, ako bi one imalo posjedovale privlačnost i draž. Zbog svoje strasti prema glazbi općenito, uz ozbiljnu njegovao je i ljubav prema salonskoj glazbi. Kako navodi prof. Prerad Detiček, dekan Muzičke akademije (1991.-1995.), zbog iskazanog interesa među studentima, ali i na Klimin nagovor formiran je Salonski orkestar Muzičke akademije. Neki izvori navode kao godinu osnutka 1992., ${ }^{27}$ dok drugi spominju 1993. ${ }^{28}$ Ideja vodilja je bila obnoviti, te očuvati tradiciju salonske glazbe. Postojala je i zamisao da se ova ideja formalizira u obliku kolegija pri Muzičkoj akademiji u kojem bi se prezentirao i obrađivao taj vid glazbe, ali ona nažalost nije zaživjela. ${ }^{29} \mathrm{Uz}$ svesrdnu podršku dekana Detičeka, a pod stručnim Kliminim okom, započele su probe ansambla. Ansambl se sastojao od četiri violine, tri viole, violončela, kontrabasa, saksofona, flaute i klarineta. ${ }^{30}$ Ponekad je saksofon bio zamijenjen oboom. ${ }^{31}$ Prvi koncert Salonskog orkestra održan je u Klubu sveučilišnih profesora u Zagrebu, najvjerojatnije 1992. godine, a izvodile su se skladbe laganijeg glazbenog sadržaja. Orkestar je održao brojne koncerte po Hrvatskoj, a korisno je istaknuti koncert u Maloj dvorani Lisinski 1994. povodom 40-e godišnjice Klimina umjetničkog rada, te nastup na pozornici HNK u Splitu 1995. godine. Izvodilački repertoar ansambla obuhvaćao je valcere, čardaše, tanga, serenade, operetnu glazbu, razne male skladbe za violinu, evergreene i druge popularne komade, a neizostavne skladbe na programu su bile one poput Tanga ljubomore, Dvořakove Humoreske i naravno čardaši Ko lijepi san i Montijev Čardaš. Kako je ljubav Klime prema salonskoj glazbi bila mnogima poznata, pijanist i skladatelj Zlatko Dvoržak posvetio je skladbu Pepi czardas njemu u čast. Prilikom koncerta održanog u povodu Klimina umjetničkog jubileja, izvedena je spomenuta skladba.

26 Prema obavijesti Vesne Šepat-Kutnar dobivenoj dana 11. 5. 2017. godine.

27 Prema obavijesti V. Mikića nekadašnjeg studenta prof. J. Klime, dobivenoj dana 25. 4. 2017. godine.

28 Prema obavijesti V. Novoselec nekadašnje studentice prof. J. Klime, dobivenoj dana 11. 5. 2017. godine.

29 Prema obavijesti tadašnjeg dekana prof. Prerada Detičeka dobivenoj dana 13. 5. 2017. godine.

30 Prema obavijesti V. Mikića nekadašnjeg studenta prof. J. Klime, dobivenoj dana 25. 4. 2017. godine.

31 Kao npr.: Koncert povodom 40-e godišnjice Klimina umjetničkog rada, Mala dvorana Lisinski, Zagreb, 1994. godine. 
Univerzalnost i inkluzivnost pristupa plijenili su pozornost njegovih suradnika, ali i publike. Ključ uspjeha se skrivao u njegovoj neiscrpnoj životnoj energiji, osobnoj kreativnosti i nesputanom šarmu. Nemiran duh vodio ga je kroz različite sfere glazbenog života. Svojim je širokim spektrom interesa, kao istaknuti hrvatski guslač, obilježio vrijeme u kojem je djelovao, a njegov zaokruženi pedagoški i umjetnički put ostaje trajna vrijednost hrvatske baštine. Uvid u njegovu ostavštinu predstavljao bi temelj sustavnog istraživanja, ali bi bio i zanimljivo i inspirativno vrelo podataka o ovom osebujnom umjetniku.

\section{LITERATURA}

1. Ivona AJANOVIĆ-MALINAR, Klima, Josip, Hrvatski biografski leksikon. http:// hbl.lzmk.hr/clanak.aspx?id=10527 (pristup 5. 5. 2017.).

2. Krešimir FILIĆ, Glazbeni život Varaždina, Varaždin, Muzička škola Varaždin, 1972.

3. Nikša GLIGO, Profinjeno. Vjesnik u srijedu. 26 (1977) 1289, str. 31.

4. Tatjana KAMALIĆ-ŠKRJANEC, Nezaboravni užitak. Novi list, 31 (1977) 125, str. 8.

5. Judita KÖRBLER, Josip, Klima, ciklus emisija „Vrijeme je za muziku“, Arhiv Hrvatskog radija, Treći program, 17. 10. 1978.

6. Erika KRPAN, Muzička akademija Sveučilišta u Zagrebu 90 godina, Zagreb, Muzička akademija Sveučilišta u Zagrebu, 2011.

7. Jagoda MARTINČEVIĆ, In memoriam Josip Klima. Glasilo Hrvatskog glazbenog zavoda, XVI (2012) 1, str. 3.

8. Mirjana ŠKUNCA, Impresivan susret s Borisom Papandopulom. Slobodna Dalmacija, 39(1981) 11219, str. 9.

9. Lovro (lž) ŽUPANOVIĆ, Violinista Josip Klima u svjetlu francuske kritike. Vjesnik, 15 (1954) 2846, str. 6.

10. Ansambl klasične glazbe - novi program Učilišta, Bilten Ansambla Pučkog otvorenog učilišta Zagreb, Zagreb: Pučko otvoreno učilište Zagreb, broj 1, prosinac 1999.

11. Dossier Josipa Klime, Muzička akademija Sveučilišta u Zagrebu.

12. Godišnjica Ansambla Pučkog otvorenog učilišta Zagreb, Bilten Ansambla Pučkog otvorenog učilišta Zagreb, Zagreb: Pučko otvoreno učilište Zagreb, broj 3, 2001.

13. Hrvatsko društvo glazbenih umjetnika: Dosadašnji dobitnici nagrade „Milka Trnina", http://www.hdgu.hr/dobitnici-nagrade-milka-trnina/ (pristup 5. 5. 2017.). 
14. Erika KRPAN: 18. PORIN, Dobitnici Porina za životno djelo Josip Klima, 28. 03. 2011. http://arhiva.porin.info/index.php?opt=news\&act=mlist\&id=44\&lan $\mathrm{g}=\mathrm{hr}$ (pristup 5. 5. 2017.).

15. Josip KLIMA - Stjepan MIHALJINEC: Ne zaboravi me, Jugoton, LP-6 202031 7, 1989.

16. Josip KLIMA - Stjepan MIHALJINEC: Ko lijepi san, Jugoton, LSY-62213, 1987. https://www.discogs.com/Josip-Klima-Stjepan-Mihaljinec-Ko-Lijepi-San/release/3125932 (pristup 14. 5. 2017).

17. Nagrade u kulturi, http://www.min-kulture.hr/default.aspx?id=407 (pristup 5. 5. 2017.).

18. Dosadašnji dobitnici nagrade Josip Štolcer Slavenski https://hr.wikipedia. org/wiki/Nagrada_Josip_\%C5\%A0tolcer_Slavenski (pristup 5. 5. 2017.).

19. Josip Klima, Plaketa HDGU povodom 40. obljetnice umjetničkoga rada. https://hr.wikipedia.org/wiki/Josip_Klima (pristup 15. 5. 2017.). 


\section{SAŽETAK \\ JOSIP KLIMA - JEDNA SVESTRANA UMJETNIČKA I PEDAGOŠKA OSOBNOST}

Josip Klima (1927. - 2012.) jedan je od najznačajnijih hrvatskih guslača druge polovice 20. stoljeća. Djelovao je kao violinski virtuoz, orkestralni i komorni glazbenik, te kao pedagog. Svojom svestranošću i osobnošću je privlačio pozornost glazbenika, publike i kritike. Široj je javnosti bio poznat kao izvođač salonske i zabavne glazbe. Pored profesionalnog bavljenja glazbom, pozornost je posvećivao amaterskom muziciranju. Dobitnik je brojnih uglednih priznanja i nagrada. U članku je kronološki prikazan njegov umjetnički i pedagoški rad, a iznesene su i neke nedoumice i neslaganja vezane uz dataciju njegova djelovanja, između sekundarne literature i primarne dokumentacije.

Ključne riječi: Josip Klima; violinist; 20. stoljeće; violinska pedagogija; salonska glazba, glazbeni amaterizam.

\section{SUMMARY}

\section{JOSIP KLIMA - AN ARTIST, VIOLIN PEDAGOGUE AND A VERSATILE PERSONALITY}

Josip Klima (1927. - 2012.) is one of the most important Croatian violinists in the second half of the twentieth century. He acted as a violin virtuoso, orchestral and chamber musician as well as a violin pedagogue. Musicians, audience and critics were attracted by his universality and personality. General public had known him as a player of salon and popular music. Besides professional activities, he also payed attention to amateur performing. He received numerous distinguished acknowledgements and awards. In this article his artistic and pedagogical lifepath is presented chronologically. However, there are some discrepances between primary documentation and secondary literature about his work, at which it was pointed in this paper.

Key Words: Josip Klima; violinist; 20th century; violin pedagogy; salon music; music amateurism. 